\title{
Performance Analysis of Development Institutions for Investment and Innovation Activities in Rostov Region
}

\author{
Kuznetsov N. G. \\ Department of Theoretical Economics \\ Rostov State University of Economics \\ Rostov-on-don, Russia \\ kuznecov@rsue.ru \\ Ponomareva M.A. \\ Department of Regional Economy, Industries and \\ Enterprises \\ Rostov State University of Economics \\ Rostov-on-don, Russia \\ yuma@list.ru
}

\author{
Tyaglov S.G. \\ Department of Regional Economy, Industries and \\ Enterprises \\ Rostov State University of Economics \\ Rostov-on-don, Russia \\ tyaglov-sg@rambler.ru
}

Rodionova N. D.

Department of Theoretical Economics

Rostov State University of Economics

Rostov-on-don, Russia

ndrodionova@mail.ru

\begin{abstract}
The article deals with the issue of working out approaches to improving performance of regional institutions for stimulation of investment and innovation activities development in the Russian Federation.

Regional innovative systems are the suppliers of innovative techniques for all economy sectors, social sector and territorial ecosystems. Particularly, much attention in the article is paid to the necessity of constant update of the so-called "best available techniques", which are to be introduced in Russian regions in the framework of the national project "Ecology".

The target of research for the article is Rostov region with its innovative system with regard to the existing institutions, promoting the investment and innovation activities. The authors have explored the core indicators of the investment and innovation development in Rostov region and implemented systematization of innovative development in existing institutions (expert organizations) considering such factors as implemented support measures for the regional innovative system subjects, targets and sources of funding. The prospective ability of correlation between the employed support measures of researchand-development and implementational works and the needs for the prospectively best available techniques in the region's production sector has been studied as a particular factor.
\end{abstract}

Keywords: region (constituent unit of the Russian Federation), Rostov region, development institutions, investment and innovation activities, best available techniques

\section{INTRODUCTION}

nnovation activities represent an important factor of national and regional socio-economic development. In this regard, encouragement of innovation activities as well as investment flows into research and development projects is considered to be a regular component of economic policy in any developed state. An efficient way of encouraging investment and innovation activities is to establish the corresponding institutions for interaction between innovative processes participants and systems with the aim to implement steps of innovations' development and introduction.

In this case, we consider institutions to be expert organizations and unions of specialists, whose activities are directed at encouragement and promotion of innovations, attraction of investors into the sphere of innovations, analysis and development of measures to support innovative activities, and establishment of interaction among investment and innovation activities' participants. These organizations play an intermediary and bridging role between different subjects of the national and regional innovative system. Very often they assume the informational and consulting roles, thus distributing information on the existing measures to support innovative activities, other participants of the innovative process in a specific area (for instance, in a subject of the Russian Federation). 


\section{LITERATURE REVIEW AND RESEARCH METHODS}

Analysis of the scientific literature on the topic of the article shows that there are a number of studies both on innovations development, encouragement of innovation activities and formation of effective innovative institutions, and on improvement of the mechanism of BAT implementation in various countries, including selection procedures, solution of compatibility problems when dealing with foreign techniques applied to the national technological systems.

An advanced area of studies is the development of innovations encouragement in the sphere of environmentally friendly, energy-efficient techniques. Because all BAT can be described this way, we can consider that such innovations will contribute to the growth of prospective BAT market.

Among the latest publications in this area we would like to single out the work by Smol M., Kulczycka J. dedicated to the issue of innovations development in the European raw material sector [2]. Palage K., Lundmark R. and Söderholm P. consider the innovation effects of renewable energy policies and their interaction (in the case of solar photovoltaics) [3]. Pitelis A.T., Vasilakos N., Chalvatzis K., Pitelis C.N. analyze whether industrial policy can foster innovation in renewable energy technologies in the OECD and in the EU regions [4]. Zemtsov S.P. and Chernov A.V. pay attention to the reasons of different growth rates in different high-tech companies in Russia [5].

Financial aspects of innovations development in cleaner energy production in OECD countries are analyzed in the study by Al Mamun M., Sohag K., Shahbaz M., Hammoudeh S. [6]. The regional aspect of innovation activities development and efficiency of indirect support for innovation activities in different regions is studied in the work by Klímová V. [7]. Analysis of econometric methods applied to the study of climate policy's impact on renewable energy technologies development is presented in the work by Böhringer C., Cuntz, A., Harhoff D., Asane-Otoo E. [8].

On the other hand, there are a number of articles on the issue of BAT implementation. Here, the most relevant lines of research are methodology development for definition and selection of BAT and European techniques' adaptation to the goals of non-European countries' economies.

For example, Roger Dijkmans offers a step-by-step procedure for selection of the industry-specific BAT, which enables to assess techniques from the point of view of their technological feasibility, economic efficiency and ecological parameters of their impact on the environment and its components [9].

H. Schollenberger, M. Treitz and J. Geldermann study the necessity to adapt techniques of BAT transfer into industrially developed countries, particularly into Chile and China, concerning the definition of its basic criteria due to differences in economic, legal and technological conditions [10].

Another important direction of studies is development of proving grounds for techniques to implement BAT at the level of enterprises and regulating authorities. In their work, A. regions in the South of Russia with a developed innovative system including existing innovative institutions and a high innovation potential. 
Cikankowitz, V. Laforest offer a general methodology aiming at providing help to all interested parties (industrialists, authorities) in their operating license update (in this case, French technical report) focusing on the evaluation of existing BAT techniques and providing a general framework for the assessment of production units and management processes [11]. Damien Evrard, Jonathan Villot, Chadad Armiyaou, Rodolphe Gaucher, Sofia Bouhrizi, Valerie Laforest offer an integrated method for multicriteria assessment of reference installations for BAT implementation on the basis of mathematical and statistical methods [12]. In their article, D. Huybrechts, A. Derden, L. Van den Abeele, S. Vander Aa., T. Smets analyze the possibility of implementation of sustainable supply chain management principles into the base of BAT definition, which can become a driver for greening global value chains [13].

The process of BAT implementation in Russia is studied by scholars too. In this approach, it is necessary to acknowledge the work by T.V. Nevalenova and O.N. Lazdina analyzing the system of voluntary environmental certification as a tool for the implementation of the best available techniques. [14]. T.V. Guseva, Ya.P. Molchanova, M.V. Begak and A.V. Mironov pay special attention to the systems of energy management and the issue of training of specialists for transfer to BAT [15].

The industry-specific aspect of BAT implementation is relevant as well. A group of scholars - I.I. Rebrik, A.G. Bernjatskij, R.V. Starshinov, I.A. Kosorukov, T.V. Guseva, S.A. Konstantinova, V.B. Sapozhnikov, I.S. Poddubnyj, O.V. Grevtsov, N.V. Kostyleva, Ja.P. Molchanova, M.V. Begak, et al. consider the specific character of BAT implementation in various industries of Russian economy - nickel industry, lead production, precious metals, mining, production of solid and other inorganic substances, etc.

Wider aspects of BAT implementation related to modernization processes, transfer to the "green economy" model and others are studied in the works by L.A. Mochalova [16], J.A. Timofeeva [17], I.N. Ovchinnikova [18].

At the same time, there are almost no studies analyzing connection between the existing development institutions for innovative activities in Russian regions and the market of prospective BAT, securing innovators' interest in the development of Russian environmentally sensitive techniques corresponding to criteria and standards of BAT.

In order to study development possibilities of Russian institutions for stimulation of innovative techniques creation, which would further supply the register of the best available techniques, using the example of Rostov region, the article analyzes the indicators of the region's innovative development, studies the region's demand for the brand new techniques and innovative activities of organizations in Rostov region, scrutinizes existing institutions for support of innovation and investment activities in the region, assesses their possible role in purposeful stimulation of prospective BAT production.

The given study uses common scientific methods such as observation and abstraction, inductive and deductive reasoning, economic, logic and comparative analysis, data grouping, normative and systematic methods, generalization of practical and theoretical data, methods of table and graphic visualization of data.

Informational and empirical basis of the data presented in the article and used for justification of the authors' conclusions is found in the official papers of Federal State Statistic Service of the RF and its regional branches in Rostov region, scientific articles by academic economists representing both Russian and foreign studies on the topic in question, the national project "Ecology", including its constituent part - the federal project "Implementation of the best available techniques", information from official portals of the executive authorities of the RF and Rostov region, internet sources, as well as the authors' practical experience of many years and their personal observations and summaries.

The legal framework of the study rests upon regulatory legal acts of the Russian Federation and Rostov region, programme-based and targeted documents concerning the issues of regulation of innovative activities and BAT implementation in the RF and regions.

\section{RESULTS}

Rostov region is one the best developed regions in the South of Russia. The region has a well-developed innovative system, which includes all participants of the innovative process, ensuring realization of its different stages. Moreover, there are a number of institutions in the region, which ensure coordination and interaction among the subjects of the innovative system.

The development of the innovative system in Rostov region is characterized by trends in a range of indicators (see Table I).

TABLE I. TRENDS IN INDICATORS OF INNOVATIVE DEVELOPMENT OF ROSTOV REGION, 2014-2017 [19]

\begin{tabular}{|l|l|l|l|l|}
\hline \multicolumn{1}{|c|}{ Indicator } & \multicolumn{1}{|c|}{$\mathbf{2 0 1 4}$} & $\mathbf{2 0 1 5}$ & $\mathbf{2 0 1 6}$ & $\mathbf{2 0 1 7}$ \\
\hline $\begin{array}{l}\text { Internal costs of scientific research } \\
\text { and development, mln rubles }\end{array}$ & 14722.6 & 13682.2 & 13663.8 & 13102.3 \\
\hline $\begin{array}{l}\text { Organizations' innovative } \\
\text { activities, \% }\end{array}$ & 9.6 & 9.9 & 8.4 & 8.2 \\
\hline $\begin{array}{l}\text { Volume of innovative goods, } \\
\text { works, services, mln rubles / \% } \\
\text { from the total volume of shipped } \\
\text { goods, executed work, provided } \\
\text { services }\end{array}$ & $\begin{array}{l}68558.1 \\
10.9\end{array}$ & $\begin{array}{l}108526.9 \\
/ 14.3\end{array}$ & $\begin{array}{l}133792.6 \\
/ 14.5\end{array}$ & $\begin{array}{l}104538.5 \\
/ 10.6\end{array}$ \\
$\begin{array}{l}\text { Number of personnel occupied with } \\
\text { scientific research and } \\
\text { development, people }\end{array}$ & 12622 & 12556 & 12102 & 11846 \\
\hline
\end{tabular}

Considering adaptation complications of foreign techniques under conditions of a certain country, which are justified by the abovementioned studies, incompatibility of some foreign technological solutions with the existing national practice is relevant for Russian economy as well [12]

A simple analysis of comparison of the number of developed and implemented leading techniques shows that a significant part of techniques implemented in Rostov region comes from outside (Table II) [12]. 
TABLE III. ANALYSIS OF INSTITUTIONS FOR INNOVATIVE DEVELOPMENT IN ROSTOV REGION FOR DEVELOPMENT AND IMPLEMENTATION OF PROSPECTIVELY BEST AVAILABLE TECHNIQUES [13]

TABLE II. RATIO OF DEVELOPED AND IMPLEMENTED ADVANCED PRODUCTION TECHNIQUES IN THE RUSSIAN FEDERATION AND ROSTOV REGION, 2014-2017 [19]

\begin{tabular}{|l|l|l|l|l|}
\hline & $\mathbf{2 0 1 4}$ & $\mathbf{2 0 1 5}$ & $\mathbf{2 0 1 6}$ & $\mathbf{2 0 1 7}$ \\
\hline Russian Federation & & & & \\
\hline Techniques developed, units & 1409 & 1398 & 1534 & 1402 \\
\hline Techniques implemented, units & 204546 & 218018 & 232388 & 240054 \\
\hline $\begin{array}{l}\text { Ratio of implemented techniques to } \\
\text { developed techniques, times }\end{array}$ & 145 & 156 & 151 & 171 \\
\hline Rostov region & & & & \\
\hline Techniques developed, units & 19 & 22 & 25 & 15 \\
\hline Techniques implemented, units & 3104 & 3047 & 3314 & 3368 \\
\hline $\begin{array}{l}\text { Ratio of implemented techniques to } \\
\text { developed techniques, times }\end{array}$ & 163 & 139 & 133 & 225 \\
\hline
\end{tabular}

Implementation of the BAT mechanism could become an additional incentive for Russian innovative organizations and enterprises.

In the article [13], we have shown that, in general, a regulatory environment has been formed in Russia, which ensures BAT implementation in industrial enterprises.

Further development of the BAT implementation mechanism requires correlation between the existing regional innovative system and goals of BAT implementation.

This correlation can be supported by institutions established in Rostov region to encourage innovation activities.

Currently, the official data provided on the website of the Government of Rostov region can be used to identify the following institutions for support of innovations which operate in the region (Table III).

\begin{tabular}{|c|c|c|}
\hline Institution & $\begin{array}{c}\text { Functions relevant for goals of } \\
\text { BAT development }\end{array}$ & $\begin{array}{c}\text { Possible role for } \\
\text { BAT goals } \\
\end{array}$ \\
\hline \begin{tabular}{ll}
\multicolumn{1}{c}{ Agency } & of \\
novations & of \\
ostov region &
\end{tabular} & & \\
\hline $\begin{array}{l}\text { Regional } \\
\text { igineering } \\
\text { nter (REC) }\end{array}$ & $\begin{array}{l}\text { organization of the engineering } \\
\text { consulting system for the subjects of } \\
\text { small and medium-sized businesses; } \\
\text { formation of technological and } \\
\text { industrial intra-industry } \\
\text { subcontracting systems; ensuring } \\
\text { interaction between the subjects of } \\
\text { small and medium-sized businesses } \\
\text { and engineering companies, as well } \\
\text { as financial institutions; help in } \\
\text { technological modernization of } \\
\text { small and medium-sized businesses } \\
\text { on favourable terms; coordination of } \\
\text { technological modernization in the } \\
\text { regional priority industries }\end{array}$ & $\begin{array}{l}\text { When } \\
\text { development } \\
\text { introduced as a } \\
\text { priority, it will } \\
\text { provide interaction } \\
\text { and cooperation } \\
\text { between various } \\
\text { participants of the } \\
\text { process at the } \\
\text { stages of scientific } \\
\text { development and } \\
\text { experimental } \\
\text { implementation of } \\
\text { the prospective } \\
\text { BAT }\end{array}$ \\
\hline $\begin{array}{l}\text { Business } \\
\text { celerator }\end{array}$ & $\begin{array}{l}\text { search for technical solutions from } \\
\text { individual developers, centers of } \\
\text { techniques transfer from higher } \\
\text { educational institutions, research } \\
\text { institutes, etc.; } \\
\text { examination of commercial viability } \\
\text { of innovative projects and } \\
\text { development of strategy for their } \\
\text { commercialization; } \\
\text { attraction of new entrepreneurs } \\
\text { willing to create high-tech start-ups, } \\
\text { project teams formation; } \\
\text { help in preparation of a document } \\
\text { package for early-stage investors; } \\
\text { attraction of funds to the projects. }\end{array}$ & $\begin{array}{lr}\text { It can } & \text { provide } \\
\text { conditions } & \text { for } \\
\text { interaction between } \\
\text { the developer of } \\
\text { prospective } & \text { BAT } \\
\text { and } & \text { the } \\
\text { implementing } \\
\text { organization } \\
\text { enterprise; } \\
\text { attraction } \\
\text { investment into the } \\
\text { development and } \\
\text { implementation of } \\
\text { BAT. }\end{array}$ \\
\hline $\begin{array}{l}\text { the } \\
\text { epresentative } \\
\text { ffice of the } \\
\text { ederal Fund for } \\
\text { ssistance to } \\
\text { nall Innovative } \\
\text { nterprises }\end{array}$ & $\begin{array}{l}\text { implementation of the programmes } \\
\text { of innovative development, creation } \\
\text { of new and development of existing } \\
\text { high-tech companies, } \\
\text { commercialization of results of the } \\
\text { scientific-development activities; } \\
\text { turning a scientific idea into a stable } \\
\text { business; } \\
\text { independent assessment of } \\
\text { innovative projects with regard to } \\
\text { their scientific and technological } \\
\text { novelty, financial and economic } \\
\text { justification, prospective sales of the } \\
\text { product on the market. }\end{array}$ & $\begin{array}{lr}\text { It can } & \text { create } \\
\text { conditions } & \text { for } \\
\text { research } & \text { and } \\
\text { implementational } \\
\text { vectors to } \\
\text { towards } & \text { BAT } \\
\text { development } & \end{array}$ \\
\hline $\begin{array}{l}\text { Innovation } \\
\text { technology } \\
\text { nters } \\
\text { nters })\end{array}$ & $\begin{array}{l}\text { sector-specific research (each center } \\
\text { is sector-specific); } \\
\text { encouragement of innovative } \\
\text { activities of the real economy } \\
\text { organizations; } \\
\text { attraction of qualified researchers } \\
\text { and specialists; } \\
\text { research base provision, etc. }\end{array}$ & $\begin{array}{l}\text { Development } \\
\text { sector-specific } \\
\text { BAT; } \\
\text { attraction } \\
\text { training and } \\
\text { researchers in the } \\
\text { BAT development } \\
\text { sector. }\end{array}$ \\
\hline $\begin{array}{l}3 . \quad \text { Working } \\
\text { groups on } \\
\text { implementation } \\
\text { of innovative } \\
\text { products and } \\
\text { innovative } \\
\text { developments } \\
(11 \text { working } \\
\text { groups) }\end{array}$ & $\begin{array}{l}\text { Consideration of the issues } \\
\text { concerning problem analysis and } \\
\text { efficiency of the measures taken to } \\
\text { implement innovative products and } \\
\text { developments }\end{array}$ & $\begin{array}{lr}\text { Analysis } & \text { of results } \\
\text { of the measures } \\
\text { introduced } & \text { to } \\
\text { implement } & \text { BAT } \\
\text { into } & \text { certain } \\
\text { industries } & \text { and } \\
\text { branches } & \text { of } \\
\text { economy } & \end{array}$ \\
\hline
\end{tabular}


Analysis of institutions for innovative development in Rostov region in the framework of the possible formation of conditions for development and experimental implementation of the prospective best available techniques carried out in Table 3 shows that, in general, the region has created a basis for stimulation of development and implementation of innovative techniques [13].

At the same time, targeted promotion of innovative developments in the sphere of prospective BAT requires taking into account BAT priority in the activities of the mentioned institutions.

\section{CONCLUSION}

Successful integration of goals connected with development and implementation of prospective BAT into the system requires their incorporation into the functions of corresponding institutions. For this, it is necessary to extend their aims and goals with the notion of BAT, BAT reference books and their characteristic as a prospectively receptive developing market of scientific research and development.

Moreover, as part of functioning of working groups on implementation of innovative products and innovative developments, it is also reasonable to form a separate intersector group on development and experimental implementation of prospective BAT, which would include representatives of authorities regulating development of industry, agriculture, conservation of the environment and natural resources, as well as those responsible for the functioning of the development institutions presented in Table III.

At the federal level, it would be reasonable to include development and experimental implementation of prospective BAT into the functions of the Federal Fund for Assistance to Small Innovative Enterprises as a separate priority.

Besides, it is necessary to consider the question of possible amendments to the federal and regional legislation regulating support for investors and innovative activities concerning changes in current measures taken to support innovative projects aimed at prospective BAT development, including specification for criteria of environmental performance, commercial efficiency, and possibility of scaling-up of the given techniques.

These measures will ensure connections between regional innovative systems and their institutions and developmental and implementational goals of BAT.

\section{ACKNOWLEDGMENTS}

The reported study was funded by RFBR according to the research project No. 19-010-00860 "The management organizational and economic mechanism formation for the sustainable regional innovation systems.

\section{REFERENCES}

[1] "The Directive on Integrated Pollution Prevention and Control", Directive 96/61/EU with the Amendments Introduced by the Directives 2003/35/ EU and 2003/87/EU, InProject Materials "Harmonization of environmental standards - II", Programme of the EU-Russia cooperation.

[2] M. Smol and J. Kulczycka, "Towards innovations development in the European raw material sector by evolution of the knowledge triangle", Resources Policy, 2019, no. 62, pp. 453-462. DOI: 10.1016/j.resourpol.2019.04.006.

[3] K. Palage, R. Lundmark, and P. Söderholm, "The innovation effects of renewable energy policies and their interaction: the case of solar photovoltaics", Environmental Economics and Policy Studies, 2019, no. 21 (2), pp. 217-254. DOI: 10.1007/s10018-018-0228-7.

[4] A. T. Pitelis, N. Vasilakos, K. Chalvatzis, and C. N. Pitelis, "Can industrial policy foster innovation in renewable energy technologies in the OECD and in EU regions?", Cambridge Journal of Regions, Economy and Society, 2019, no. 12 (2), pp. 271-292. DOI: $10.1093 /$ cjres/rsz005.

[5] S. P. Zemtsov and A. V. Chernov, "What high-tech companies in Russia grow faster and why?", Zhournal Novoi Ekonomicheskoi Associacii, 2019, mo. 41 (1), pp. 68-99. DOI: 10.31737/2221-22642019-41-1-3.

[6] M. Al Mamun, K. Sohag, M. Shahbaz, and S. Hammoudeh, "Financial markets, innovations and cleaner energy production in OECD countries", Energy Economics, 2018, no. 72, pp. 236-254. DOI: 10.1016/j.eneco.2018.04.011.

[7] V. Klímová, "How do regions use indirect support for their innovation activities?", Scientific Papers of the University of Pardubice, Series D: Faculty of Economics and Administration, 2018, no. 25 (42), pp. 104 115.

[8] C. Böhringer, A. Cuntz, D. Harhoff, and E. Asane-Otoo, "The impact of the German feed-in tariff scheme on innovation: Evidence based on patent filings in renewable energy technologies", Energy Economics, 2017, no. 67, pp. 545-553. DOI: 10.1016/j.eneco.2017.09.001.

[9] R. Dijkmans, "Methodology for Selection of the Best Available Techniques (BAT) at the Sector Level", Journal of Cleaner Production 8, 2000, 11. DOI: https://doi.org/10.1016/S0959-6526(99)00308-X.

[10] H. Schollenberger, M. Treitz, and J. Geldermann, "Adapting the European Approach of Best Available Techniques. Case Studies from Chile and China", Journal of Cleaner Production, 2008, no. 16 (17), $1856 \mathrm{p}$.

[11] A. Cikankowitz and V. Laforest, "Using the BAT Performance as an Evaluation Method of Techniques", Journal of Cleaner Production, 2013, no. 42 141. DOI: https://doi.org/10.1016/j.jclepro.2012.10.005.

[12] N. G. Kuznetsov, S. G. Tyaglov, M. A. Ponomareva, and N. D. Rodionova, "Innovations as a Source of the Best Available Technique in Russia", IOP Publishing, Forestry 2019 IOP Conf. Series: Earth and Environmental Science, 2019, 392, 012028 p. DOI: doi:10.1088/17551315/392/1/012028

[13] N. G. Kuznetsov, S. G. Tyaglov, M. A. Ponomareva, and N. D. Rodionova, "Development of regional innovation support institutions for the implementation of the best available technologies", Materials of the International Conference "Process Management and Scientific Developments", Birmingham, United Kingdom, 30 November, 2019, pp. $14-18$.

[14] T. V. Nevalenova and O. N. Lazdina, "A System of Voluntary Environmental Certification as a Tool for the Implementation of the Best available techniques", Exposition Oil Gas [Ekspozitsiya Neft' Gaz - in Russian], 2015, 3, 77.

[15] T. V. Guseva, Ya. P. Molchanova, M. V. Begak, and A. V. Mironov, "The Best available techniques as an Instrument of Industrial and Environmental Policy", Bulletin of the Russian Chemical techniquey University named after D.I. Mendeleev: Humanitarian and Socioeconomic Research, Vestnik Rossiyskogo khimiko-tekhnologicheskogo universiteta im. D.I. Mendeleyev: gumanitarnyye i sotsial'noekonomicheskiye issledovaniya, 2015, 2 (6) 62. 
[19] "Regions of Russia, Socio-economic indicators, 2018", Statistical book, Rosstat, M., 2018 [Electronic resource]. Available at: https://www.gks.ru/storage/mediabank/reg-pok\%2018.pdf.

[16] L. A. Mochalova, "Ecological Aspects of the Modernization of the Russian Economy", News of the Ural State Mining University, 2016, 3 105. DOI: 10.21440/2307-2091-2016-3-105-108.

[17] J. A. Timofeeva, G. Y. Belyakova, and N. A. Shumakova, "The Best available techniques - a Chance for a Green Economy", In Youth, Society, Modern Science, techniquey and Innovation, 2016, pp. 287289.

[18] I. N. Ovchinnikova, "The Best available techniques in the Basis of Environmental Management", In Geography and Ecology: Scientific Sreativity, Snterdisciplinarity, Educational techniqueies Materials of the International Scientific-practical Sonference, Res. editor Yu.M. Grishaeva (Moscow), 2017, pp. 117-123.

[20] "The Best available technique. Application in Various Industries", In Collection of articles 4, Moscow: Publishing House "Pero", 2016, 176 p.

[21] Electronic resource. Available at: https://www.donland.ru/activity/2423/.

[22] Electronic resource. https://www.donland.ru/activity/1402/.

[23] Electronic resource.

Available at: https://www.donland.ru/activity/1403/.

Available at: 